\title{
KALIMAT TANYA DALAM BAHASA INDONESIA
}

\author{
Mariam L. M. Pandean \\ mariampandean@unsrat.ac.id \\ Universitas Sam Ratulangi
}

\begin{abstract}
Interrogative sentence is one kind of sentences in Indonesian, which formed as proposition that required answer from hearer. It also called as requesting question. The difference will be recognized from sentence classification perspective. In defining interrogative sentence, syntax, semantics, and pragmatics can be used as the classification tool (Leech, 1981). From syntactic point of view, there are two kinds of interrogative sentence; 1) informative interrogative sentence and 2) confirmative interrogative sentence. Informative interrogative sentence has information request toward one of the element the proposition maker. In this context, proposition maker element can fill one of the syntactic function slot in sentence as function of predicate, object, and complement. But confirmative interrogative sentence requires for distinction of a proposition. Practically, the form is yes or no question. Syntactically, interrogative in Indonesian can be recognized from the question word used. There are many varieties of this type. However, only two elements serve as the basis of interrogative sentence; they are what and where. The derivation of the word apa are who, why, when, how much or how many, and if; the derivation of the word mana are where, where to, from where, how, and when. Semantically, interrogative sentence can be identified from its semantic role of the word that filled the syntactic slot; they are function of predicate, object and complement. In subject function, interrogative sentence can explain the meaning of a deed, time, agent, amount, existence and identity. In object function, it can explain meaning of the target, object, and tool. In semantic role, it can explain the meaning of place, time, member, tool, meaning, cause and target.
\end{abstract}

Keyword: Interrogative sentence, Indonesian language, kind of interrogative sentence

\section{PENDAHULUAN}

Kalimat Tanya sebagai salah satu jenis kalimat bahasa Indonesia, merupakan fenomena yang menarik untuk dikaji. Dikatakan demikian karena sebagai fenomena kebahasaan dan pemakaian bahasa, kalimat tanya memiliki karakteristik yang sangat unik. Sebagai satuan gramatik, kalimat tanya tidak hanya menampilkan suatu struktur dan makna tertentu, tetapi juga mengimplikasikan situasi komunikasi dan interaksi antarpemakainya. Oleh karena itu, kalimat tanya tidak hanya dikaji dari segi sintaksis dan semantik, tetapi juga dapat ditelaah dari segi pragmatik maupun interaksional. 
Ditinjau dari segi sintaksis, kalimat tanya adalah salah satu jenis kalimat bahasa Indonesia yang memiliki ciri-ciri tertentu, antara lain: berintonasi tanya, berstruktur sintaktik kalimat tanya (menggunakan kata tanya, partikel tanya, pembalikan urutan) dan juga berdistribusi tanya. Sementara itu, dari segi semantik, kalimat tanya merupakan tuturan yang proposisinya berupa permintaan informasi atau permintaan konfirmasi, sekalipun dalam kenyataan pemakainnya tidak selalu demikian. Tuturan yang berbentuk kalimat tanya, "Mau ke mana Pak?" atau "Berangkat ke kantor, Bu?" yang diucapkan oleh seseorang yang telah kita kenal dengan baik bukanlah permintaan informasi, tetapi lebih bersifat basa-basi.

Ditinjau dari segi pragmatik, kalimat tanya merupakan tuturan yang tidak saja berfungsi untuk meminta informasi atau konfirmasi, tetapi dapat pula difungsikan untuk memberikan perintah, memulai percakapan, menandai hubungan antara pelaku percakapan, atau bahkan menyatakan dan mempertanyakan status, dan sejenisnya.

Secara interaksional, kalimat tanya merupakan salah satu unsur pembentuk interaksi. Kegiatan interaksi dibangun oleh komponen-komponen interaksi, yaitu (1) pelaku interaksi, (2) konteks yang melatari interaksi, dan (3) media interaksi yang digunakan. Media interaksi yang digunakan dapat berupa media verbal, media nonverbal, atau gabungan dari kedua media tersebut. Media verbal berwujud bahasa yang di dalamnya terdapat unsur-unsur kebahasaan yang berupa kalimat. Salah satu di antara kalimat-kalimat itu adalah kalimat tanya.

Berdasarkan uraian tersebut, dapat dikatakan bahwa masih banyak permasalahan yang berkaitan dengan kalimat tanya dalam bahasa Indonesia. Pengkajian terhadap permasalahan kalimat tanya itu dapat dilakukan dari berbagai segi, antara lain: dari segi sintaktis, semantis, pragmatik, dan interaksional.

Sehubungan dengan itu, makalah ini bermaksud mengkaji permasalahn kalimat tanya bahasa Indonesia dari segi sintaksis dan semantik, terutama dalam hal: (1) jenis-jenis kalimat tanya dalam bahasa Indonesia; (2) ciri-ciri kalimat tanya dalam bahasa Indonesia dari segi sintaktis; dan (3) ciri-ciri kalimat tanya dalam bahasa Indonesia ditinjau dari segi semantis.

\section{KONSEP TEORITIS KALIMAT TANYA BAHASA INDONESIA}

\subsection{Pengertian Kalimat Tanya}

Pembicaraan mengenai kalimat tanya dalam bahasa Indonesia telah banyak dilakukan oleh para ahli bahasa. Misalnya, Ramlan (1986) dengan tulisannya yang berjudul Sintaksis 
Bahasa Indonesia, Moeliono dkk. (1983) dalam bukunya yang berjudul Tata Bahasa Baku Bahasa Indonesia, Kridalaksana (1984) dengan tulisannya yang berjudul Kelas Kata dalam Bahasa Indonesia, Samsuri (1984) dalam Analisis Bahasa, Verhaar (1992) dalam Pengantar Linguistik, Keraf (1984) dalam bukunya yang berjudul Tatabahasa Indonesia, dan masih banyak lagi.

Kalimat tanya sering juga dikenal dengan sebutan kalimat interogatif atau kalimat permintaan. Perbedaan penyebutan ini disebabkan oleh perbedaan sudut tinjauan dalam pengklasifikasian kalimat. Dikatakan oleh Leech (1981), ada tiga sudut tinjauan yang dapat digunakan sebagai dasar pengklasifikasian suatu kalimat, yaitu sintaksis, semantik, dan pragmatik.

Dari tinjauan sintaksis, kalimat tanya mengacu pada pengertian kalimat interogatif. Kridalaksana (1984) mendefinisikan kalimat interogatif sebagai bentuk verba atau kalimat yang digunakan untuk mengungkapkan pertanyaan. Di sisi lain, disebutkan bahwa yang dimaksud dengan kalimat interogatif adalah suatu kalimat yang mengandung makna pertanyaan. Selanjutnya, ia mencirikan kalimat interogatif dalam bahasa Indonesia tulis dengan ciri-ciri: ditandai oleh tanda baca (?) dan secara gramatikal ditandai dengan partikel $k a h$, atau pemakaian kata-kata seperti apa, mana, apakah, bagaimana, dan sebagainya.

Menurut Moeliono dkk. (1993:404-405), kalimat interogatif atau sering disebut kalimat tanya adalah suatu kalimat yang secara formal ditandai oleh kehadiran kata tanya seperti apa, siapa, berapa, kapan, dan bagaimana dengan atau tanpa partikel kah sebagai penghalus. Kalimat tanya tersebut juga ditandai dengan tanda tanya (?) pada bahasa tulis dan pada bahasa lisan dengan suara menaik. Terutama kalau tidak ada kata tanya, atau suara turun.

Senada dengan itu, Ramlan (1986:33) mengemukakan kalimat tanya pada umumnya berfungsi untuk menanyakan sesuatu. Kalimat tanya memiliki pola intonasi yang berbeda dengan pola intonasi kalimat berita. Perbedaan kedua kalimat tersebut terletak pada nada akhirnya. Pola intonasi kalimat berita bernada akhir turun, sedangkan pola intonasi kalimat tanya bernada akhir naik. Di samping itu, nada suku terakhir kalimat tanya lebih tinggi sedikit dibandingkan dengan nada suku terakhir pola intonasi kalimat berita. Selanjutnya, ia juga mengatakan bahwa kata-kata -kah, apa, apakah, bukan, dan bukankah, siapa, siapakah, mengapa, kenapa, bagaimana, mana, bilamana, kapan, bila, dan, berapa sering digunakan sebagai ciri kalimat tanya bahasa Indonesia. 
Ditinjau dari segi semantik, konsep kalimat tanya mengacu pada pengertian permintaan informasi (question). Berkenaan dengan itu, Cook (1971) mengartikan kalimat tanya sebagai kalimat yang dibentuk untuk memancing responsi yang berupa jawaban. Dengan maksud yang kurang lebih sama, Keraf (1984) menyatakan bahwa yang dimaksud dengan kalimat tanya adalah kalimat yang mengandung suatu permintaan agar seseorang diberi tahu karena tidak mengetahuinya.

Dari beberapa pendapat tersebut, dapat disimpulkan bahwa kalimat tanya adalah suatu kalimat yang pada hakikatnya menanyakan sesuatu atau menginginkan suatu jawaban. Secara ketatabahasaan, kalimat tanya adalah suatu kalimat yang dicirikan oleh penanda-penanda formal yang berwujud bentuk-bentuk kebahasaan dan berfungsi untuk memperoleh keterangan dari lawan bicara.

\subsection{Jenis dan Ragam Kalimat Tanya}

Berdasarkan jenisnya, kalimat tanya dapat dibedakan menjadi dua macam, yaitu (1) kalimat tanya yang memerlukan jawaban ya, tidak, atau belum; dan (2) kalimat tanya yang jawabannya berdasarkan kata tanya yang digunakan. Dengan kata lain, kalimat tanya tersebut atas pertanyaan untuk diiyakan atau diingkari dan pertanyaan yang meminta jenis keterangan. Jenis kalimat tanya yang pertama dikenali dengan empat hal, yakni (1) intonasi yang digunakan; (2) pengingkaran dilakukan dengan menggunakan kata-kata tidak, bukan, atau belum; (3) kadang-kadang menggunakan kata adakah atau apakah; dan (4) penekanan dilakukan dengan cara menggunakan aksen atau menempatkan bagian yang ditanyakan pada awal kalimat dengan disertai partikel -kah. Jenis pertanyaan yang kedua menggunakan kata-kata tanya: apa, siapa, bagaimana, mengapa, berapa, kapan, dan sebagainya.

Berdasarkan model responsi yang mengikuti kalimat tanya, Ramlan (1986) membedakan kalimat tanya menjadi dua jenis, yakni pertanyaan ya-tidak yang membutuhkan jawaban ya atau tidak dan pertanyaan perihal yang memerlukan jawaban berupa penjelasan. Ciri penanda pertanyaan ya-tidak berupa penggunaan intonasi tanya (pada kalimat berita), penggunaan partikel -kah, penggunaan kata apa, apakah, bukan, dan bukankah. Sedangkan ciri penanda pertanyaan perihal berupa penggunaan kata-kata tanya: apa, siapa, mengapa, bagaimana, mana, bilamana, bila, kapan, dan berapa. 
Senada dengan Ramlan, Keraf (1984) membedakan kalimat tanya berdasarkan jabannya atas: (a) pertanyaan total, yaitu pertanyaan yang biasanya menghendaki jawaban ya atau tidak dan; (b) pertanyaan parsial, yaitu pertanyaan yang menghendaki jawaban sesuai dengan yang dipentingkan. Untuk pertanyaan total penggunaan intonasi tanya merupakan keharusan, sebaliknya untuk pertanyaan parsial penggunaan intonasi tanya bersifat manasuka.

Berkenaan dengan pencirian kalimat tanya, Keraf (1984) mengemukakan tiga ciri sintaksis kalimat tanya, yaitu: (1) digunakan intonasi tanya; (2) digunakan kata tanya; dan (3) digunakan partikel kata tanya -kah. Dalam praktiknya, ciri pertama dan kedua bersifat komplementer. Maksudnya, kedua ciri tersebut dalam konstruksi kalimat tanya saling melengkapi. Jika suatu konstruksi tanya tidak menggunakan kata tanya, kehadiran intonasi tanya bersifat wajib. Sebaliknya, jika konstruksi tanya menggunakan kata tanya, maka kehadiran intonasi bersifat manasuka, artinya dapat hadir, boleh juga tidak. Lebih lanjut, Samsuri (1986) mengkodifikasikan intonasi tanya sebagai ciri dari kalimat tanya dengan titinada \#23(//)2232\#. Sehubungan dengan kata-kata tanya yang digunakan dalam kalimat tanya, Keraf (1984) mengelompokkannya berdasarkan sifat dan maksud pertanyaan itu sebagai berkut: (1) kata tanya apa digunakan untuk menanyakan benda, (2) kata tanya siapa untuk menanyakan manusia, (3) kata tanya berapa untuk menanyakan jumlah, (4) kata tanya mana untuk menanyakan tentang pilihan atas hal atau barang, (5) kata tanya ke mana, di mana, dari mana untuk menanyakan tempat, (6) untuk menanyakan waktu digunakan kata tanya bila, bilamana, kapan, (7) kata tanya bagaimana, mengapa digunakan untuk menanyakan keadaan, dan (8) kata tanya mengapa, apa sebab digunakan untuk menanyakan alasan.

Sejalan dengan pendapat di atas, Ramlan (1984) mengelompokkan kata-kata tanya yang digunakan dalam kalimat tanya itu sebagai berikut: (1) kata tanya apa digunakan untuk menanyakan benda, tumbuh-tumbuhan, hewan, dan identitas, (2) kata tanya siapa digunakan untuk menanyakan Tuhan, malaikat, dan orang, (3) kata tanya mengapa digunakan untuk menanyakan perbuatan dan sebab, (4) kata tanya kenapa dipakai untuk menayakan sebab, (5) kata tanya bagaimana untuk menanyakan keadaan, (6) kata tanya mana digunakan untuk menanyakan tempat, asal seseorang, (7) kata tanya bila, bilamana, dan kapan dipakai untuk menanyakan waktu, dan (8) kata tanya berapa dipakai untuk menanyakan bilangan atau jumlah. 


\section{PEMBAHASAN}

\subsection{Jenis dan Ragam Kalimat Tanya Bahasa Indonesia}

Ditinjau dari segi sintaktisnya, dengan dukungan hasil-hasil penelitian secara sintaksis, kalimat tanya dalam bahasa Indonesia dapat dikelompokkan menjadi dua jenis, yaitu (1) kalimat tanya informatif dan (2) kalimat tanya konfirmatif. Berikut diuraikan masing-masing jenis kalimat tanya tersebut.

Kalimat tanya informatif adalah kalimat tanya yang berisi permintaan informasi terhadap salah satu unsur pembentuk proposisi. Dalam hal ini unsur pembentuk proposisi tanya tersebut dapat menduduki salah satu fungsi sintaktis tertentu dalam kalimat. Luas tidaknya proposisi yang diminta bergantung pada pembentuk proposisi tanya yang berupa kata-kata tanya, seperti apa, siapa, mengapa, berapa, bagaimana, kapan, mana, dan sebagainya, sekaligus variasi bentuk masing-masing kata tanya itu.

Kalimat-kalimat tanya berikut ini menunjukkan perbedaan keluasan informasi yang dituntut karena kata-kata tanya yang digunakan.

(1) Berapa orang mahasiswa yang tewas dalam Tragedi Jembatan Semanggi?

(2) Bagaimana mereka meninggal dunia?

proposisi yang dituntut dalam kalimat (1) bersifat terbatas, yakni empat belas orang. Sedangkan kalimat (2) memerlukan proposisi yang lebih luas karena proposisi yang diminta menyangkut proses.

Sesuai dengan ciri semantisnya, kalimat tanya konfirmatif berisi permintaan ketegasan atas suatu proposisi. Secara ajeg, pertanyaan konfirmatif ini diperankan oleh kalimat tanya ya-tidak. Dikatakan demikian karena lazimnya jenis pertanyaan konfirmatif meminta jawaban ya atau tidak. Jawaban $y a$, jika yang ditanya mengiyakan atau menyetujui proposisi pertanyaan, sedangkan jawaban tidak/bukan diberi jika yang ditanya menolak atau mengingkari proposisi pertanyaan. Sudaryanto (1983) menyebut jenis pertanyaan ini sebagai jenis pertanyaan keniscahyaan, karena proposisi pertanyaan memang bertujuan untuk memperoleh pembenaran atau pengingkaran dari orang lain.

Jenis kalimat tanya konfirmatif ini dapat dibedakan menjadi dua macam jika dilihat dari unsur pembentuk proposisi tanya, yaitu (1) menggunakan intonasi tanya, dan (2) menggunakan partikel tanya. Kalimat tanya konfirmatif yang menggunakan intonasi tanya dapat dilihat pada contoh data berikut. 
(3) Iwan meninggal dunia?

(4) Para demonstran bentrok dengan aparat keamanan?

kalimat-kalimat tersebut dalam pelafalannya disertai dengan intonasi naik pada akhir kalimat.

Di samping kalimat tanya konfirmatif dengan intonasi tanya, ada jenis kalimat tanya konfirmatif lain yang menggunakan partikel tanya seperti, kah, apa, kan, dan ya. Berikut contoh kalimat tanya konfirmatif jenis kedua.

(5) Itukah hasil demonstrasi?

(6) Apa MPR perlu mengadakan sidang istimewa?

(7) Di Jakarta terjadi kerusuhan, kan?

(8) Mantan presiden Soeharto jadi diadili, ya?

Kehadiran partikel tanya dalam kalimat-kalimat tanya tersebut berada diluar prediksi. Jadi, tidak menjadi bagian dari peran semantik unsur-unsur yang mengisi fungsi kalimat. Kehadirannya hanya mendukung terbentuknya proposisi tanya saja.

Berdasarkan pemaparan di atas, secara sintaktis, kalimat tanya bahasa Indonesia dapat diidentifikasi dari: (1) penggunaan intonasi tanya, (2) penggunaan kata-kata tanya, (3) penggunaan partikel tanya, dan (4) penggunaan pengingkaran: tidak, bukan, atau belum pada akhir kalimat tanya. Berdasarkan hal tersebut, dalam bahasa Indonesia dikenal dua macam kalimat tanya, yaitu (1) kalimat tanya informatif yang memerlukan jawaban berupa penjelasan, dan (2) kalimat tanya konfirmatif yang memerlukan jawaban ya atau tidak.

\subsection{Ciri-ciri Sintaktis Kalimat Tanya Bahasa Indonesia}

Kalimat tanya bahasa Indonesia dapat juga diidentfikasi dari pemakaian kata-kata tanya. Sebagai penanda kalimat tanya, kata-kata tanya memiliki jumlah yang banyak dan beragam. Akan tetapi jika dikaji dari segi bentuknya, hanya terdapat dua unsur yang mendasari, yaitu kata tanya apa dan mana (Moeliono, 1988). Dari kedua unsur tersebut, muncul kata-kata tanya yang mengikuti pola-pola sebagai berikut. Dari kata tanya apa muncul kata-kata tanya apa, siapa, mengapa, kenapa, kapan, berapa, dan apabila. Sedangkan dari kata tanya mana menghadirkan kata-kata tanya: di mana, ke mana, dari mana, bagaimana, dan bilamana.

Walaupun kata-kata tanya tersebut berawal dari dua unsur di atas, tetapi dalam kenyataannya pemakaian kata-kata tanya itu memiliki peran yang berbeda, baik sebagai pengisi 
fungsi, maupun peran semantik yang ditimbulkannya. Berkenaan dengan itu, dalam uraian ini disajikan secara selektif pemakaian kata-kata tanya tersebut dalam bahasa Indonesia.

\subsubsection{Kata Tanya Apa}

Kata tanya apa memiliki dua peran yang berbeda secara sintaktis. Pertama, kata tanya apa dapat mengubah kalimat berita menjadi kalimat tanya. Dalam pemakainnya, kata tersebut berdistribusi pada awal kalimat berita yang diubahnya. Misalnya, contoh kalimat berikut.

(9a) TNI menyatakan sikap politiknya terhadap para reformis. (kalimat berita)

(9b) Apa TNI menyatakan sikap politiknya terhadap pernyataan para reformis? (kalimat tanya)

(10a) Aparat penembak Iwan belum diketahui. (kalimat berita)

(10b) Apa aparat penembak Iwan belum diketahui. (kalimat tanya)

kalimat (9a) dan (10a) adalah kalimat berita. Keduanya berubah menjadi kalimat tanya (9b) dan (10b) karena ditambahkan kata tanya apa pada awal kalimat-kalimat tersebut.

Kedua, kata tanya apa juga dapat menggantikan benda atau hal yang ditanyakan yang menduduki fungsi sintaktis tertentu, seperti: predikat, objek, atau pelengkap. Berikut contoh kata tanya apa digunakan untuk menanyakan fungsi-fungsi sintaktis tersebut.

(11a) Perusuh itu sedang berusaha membakar swalayan.

(11b) Perusuh itu sedang apa?

Dari beberapa contoh pemakaian kata tanya apa sebagai terurai di atas, dapat disimpulkan bahwa kata tanya tersebut dapat menggantikan fungsi-fungsi sintaktis, predikat, objek, pelengkap, dan juga keterangan (keterangan cara). Dalam fungsinya sebagai pengganti predikat, kata tanya apa dapat mengakibatkan perubahan bentuk kalimat, yaitu dari kalimat bentuk aktif menjadi kalimat bentuk pasif. Sebaliknya, dalam fungsinya sebagai pengganti objek, pelengkap, maupun keterangan, kata tanya apa tidak dapat mengubah struktur kalimat sama sekali, kecuali fungsi sintaktis yang digantikannya. Misalnya dalam contoh kalimat-kalimat tanya berikut.

(17a) Batu besar itu menyebabkan salah seorang aparat itu mati.

(17b) Apa yang menyebabkan salah seorang aparat itu mati?

(17c) Yang menyebabkan salah seorang aparat mati adalah batu besar.

(18a) Kematian ayahnya membuat Erna putus asa.

(18b) Apa yang membuat erna putus asa?

(18c) Yang membuat Erna putus asa adalah kematian ayahnya.

(19a) Perampok itu sedang berkeliaran di toko-toko.

(19b) Perampok itu sedang apa di toko-toko? 
(20a) Mereka itu melihat berita kerusuhan.

(20b) mereka itu melihat apa?

(21a) Perusuh itu membakar Ramayana.

(21b) Perusuh itu membakar apa?

(22a) Gaji menteri dipotong untuk krisis moneter selama satu tahun.

(22b) Gaji menteri dipotong untuk apa selama setahun?

\subsubsection{Kata Tanya Siapa}

Kata tanya siapa memiliki kemiripan perilaku sintaktis dengan kata tanya apa. Dengan demikian, ia juga dapat menggantikan fungsi-fungsi sintaktis: subjek, predikat, objek, atau keterangan. Misalnya, contoh kalimat-kalimat tanya berikut ini.

(23a) Anton melihat kejadian perampokan itu. (kalimat berita)

(23b) Siapa yang melihat keadian perampokan itu? (kalimat tanya)

(24a) Perampoknya para preman. (kalimat berita)

(24b) Perampoknya siapa? (kalimat tanya)

(25a) Ibu mencari Etty. (kalimat berita)

(25b) Ibu mencari siapa? (kalimat tanya)

Contoh kalimat tanya di atas menunjukkan bahwa kata tanya siapa dapat menggantikan fungsi predikat pada kalimat (23b) dan (24b), menggantikan fungsi objek pada kalimat (25b), dan menggantikan fungsi keterangan bersama-sama untuk, pada, atau dengan pada kalimat (26b). Sebagai pengganti fungsi predikat, kata tanya siapa yang diposisikan pada awal kalimat mendahului nomina tidak memerlukan bentuk yang. Sebaliknya, bentuk yang diperlukan jika kata tanya tersebut mendahului verba atau kategori kata yang lain. Bandingkan contoh-contoh kalimat-kalimat tanya berikut.

(27) Siapa yang menggerakkan demonstrasi dewas ini?

(28) Siapa yang bertanggung jawab terhadap kematian enam mahasiswa Trisakti?

Di samping itu, kata tanya siapa dapat juga mengakibatkan perubahan bentuk kalimat, dari bentuk kalimat aktif menjadi kalimat pasif, apabila kata tanya siapa sebagai pengganti fungsi objek diposisikan di awal kalimat, dengan demikian, kata tanya siapa menggantikan fungsi predikat diikuti oleh fungsi subjek dengan bentuk yang. Bandingkan pemakaian kata tanya siapa sebagai pengganti fungsi objek dan fungsi predikat dalam kalimat tanya berikut ini.

(29) Pemerintah mencari siapa?

Siapa yang dicari pemerintah?

(30) Aparat keamanan memukuli siapa?

Siapa yang dipukuli aparat keamanan? 
Dari contoh-contoh tersebut dapat disimpulkan bahwa kata taya siapa memiliki prilaku sintaktis yang mirip dengan kata tanya apa. Perbedaan antara keduanya adalah kata tanya siapa harus adanya nomina yang digantikannya, sementara kata tanya apa dapat berfungsi semata-mata sebagai penanda kalimat tanya; kata tanya siapa mengacu pada manusia, malaikat, dan bahkan Tuhan, sedangkan kata tanya apa mengacu pada hal, benda, binatang, maupun tumbuhan.

Seperti halnya kata tanya apa, kata tanya siapa dapat pula berkombinasi dengan preposisi dari, dengan, untuk, pada, atau dengan bentuk kata saja, sehingga membentuk konstruksi dari siapa, dengan siapa, untuk siapa, pada siapa, dan siapa saja. Konstruksi tersebut memiliki fungsi sintaktis sebagai keterangan dan predikat. Kata tanya siapa berkombinasi dengan kata saja dapat menggantikan fungsi predikat dan berimplikasi kejamakan. Lihat contoh kalimat berikut.

(31) Dia merampok toko-toko dengan siapa?

(32) Pak Harto menjadi presiden selama 30 tahun itu untuk siapa?

(33) Dengan siapa anak itu keluar?

(34) Siapa saja yang ditangkap aparat keamanan?

\subsubsection{Kata Tanya Mengapa dan Kenapa}

Kata tanya mengapa sering bervariasi pemakaiannya dengan kenapa. Hal ini disebabkan fungsi kedua kata tanya tersebut relatif sama, yaitu menanyakan sebab atau perbuatan.

Sebagai ciri penanda sintaktis, kata tanya mengapa dan kenapa dapat menggantikan fungsi predikat dan keterangan. Berikut ini contoh-contoh kalimat tanya yang menggantikan fungsi predikat dan keterangan.

(35) Preman-preman itu sedang mengapa?

(36) Para mahasiswa itu kenapa?

(37) Mengapa orang-orang membakar toko-toko?

(38) Kenapa mereka mengambili barang-barang?

Dari data di atas tampak kata tanya mengapa dan kenapa dalam kalimat (35) dan (36) menduduki fungsi predikat, sedangkan kata tanya kenapa dan mengapa dalam kalimat (37) dan (38) menduduki fungsi keterangan.

Walaupun kata tanya mengapa dan kenapa memiliki kesamaan kedudukan, yaitu menggantikan fungsi predikat dan keterangan, kedua kata tanya tersebut memiliki perbedaan distribusi. Dengan kata lain, dalam suatu posisi tertentu kata tanya mengapa tidak dapat digantikan oleh kata tanya kenapa. Misalnya dalam contoh berikut. 
(39a) Para aparat keamanan sedang mengapa di setiap persimpangan jalan?

(39b) *Para aparat keamanan sedang kenapa di setiap persimpangan jalan?

(40a) * Bapak berhenti merokok mengapa, sih?

(40b) Bapak berhenti merokok kenapa, sih?

\subsubsection{Kata Tanya Bagaimana}

Kata tanya bagaimana berfungsi untuk menanyakan keadaan sesuatu, cara sesuatu perbuatan itu dilakukan, atau cara sesuatu peristiwa itu terjadi. Sebagai salah satu ciri sintaktis kalimat tanya, kata tanya bagaimana dapat menggantikan fungsi predikat dan keterangan. Berikut contoh-contoh kalimat tanya yang menggunakan kata tanya bagaimana untuk menggantikan fungsi sintaktis predikat dan keterangan.

(41) Bagaimana hasil pemeriksaan dokter terhadap kematian Iwan ?

(42) Bagaimana nasib mahasiswa yang cacat itu?

(43) Bagaimana aparat keamanan dapat menembaki para demonstran?

(44) Bagaimana pemerintah mengatasi krisis ekonomi?

Data (41) dan (42) menunjukkan bahwa kata tanya bagaimana menggantikan fungsi predikat, sedangkan kata tanya bagaimana pada data (43) dan (44) menggantikan fungsi keterangan.

Di samping dicirikan dengan intonasi tanya dan kata-kata tanya, kalimat tanya dalam bahasa Indonesia juga dicirikan dengan pertikel tanya. Partikel tanya tersebut adalah partikel $a p a$, partikel -kah, partikel -kan, patikel ya, dan partikel masa?.

Bentuk-bentuk kebahasaan tersebut diidentifikasi sebagai partikel tanya berdasarkan sifat kerelasiannya dalam suatu konstruksi. Berdasarkan kriteria tersebut, partikel tanya dapat diidentifikasi dengan ciri-ciri: (1) tidak menjadi atau menggantikan fungsi tertentu dalam konstruksi kalimat dan (2) kehadirannya semata-mata sebagai salah satu unsur pembentuk kalimat tanya. Pertikel tanya tersebut dalam pembahasan ini tidak dibicarakan.

\subsection{Ciri-ciri Semantis Kalimat Tanya Bahasa Indonesia}

Ditinjau dari segi semantik, kalimat tanya bahasa Indonesia dapat dicirikan berdasarkan dua kriteria, yaitu (1) berdasarkan isi responsi yang dituntut oleh pertanyaan maka kalimat tanya dibedakan menjadi dua jenis, yakni (1) kalimat tanya ya-tidak dan (2) kalimat tanya perihal. Yang pertama dicirikan dengan pemakaian intonasi tanya dan partikel tanya: apa, -kah, -kan (bukan), ya, dan masa?. Sedangkan yang kedua dicirikan dengan pemakaian kata-kata tanya, 
seperti apa, siapa, mengapa, kenapa, bagaimana, berapa, dan sebagainya seperti yang telah diuraikan pada sub-sub sebelumnya.

Berdasarkan kriteria struktur semantisnya, maka kalimat tanya dapat dicirikan dari peran semantis kata-kata tanya yang digunakan sebagai pembentuk proposisi pertanyaan. Dalam hal ini unsur pembentuk proposisi tanya tersebut dapat menggantikan fungsi-fungsi sintaktis tertentu. Berdasarkan hal tersebut, berikut dipaparkan ciri-ciri semantis kalimat tanya ditinjau dari peran semantis kata tanya sebagai pengisi fungsi-fungsi sintaktis.

\subsubsection{Kata Tanya sebagai Pengisi Fungsi Predikat}

Kata-kata tanya dalam kalimat tanya bahasa Indonesia sebagai pengisi fungsi predikat memiliki beberapa jenis. Jenis-jenis kata tanya tersebut memiliki pula peran semantis yang berbeda. hal ini dapat dilihat dalam contoh-contoh berikut.

(45) Para mahasiswa sedang mengapa?

(46) Bagaimana luka mahasiswa yang dipukuli aparat keamanan itu?

(47) Penembak Iwan mahasiswa Atma Jaya itu siapa?

(48) Berapa korban pihak mahasiswa pada peristiwa Jembatan Semanggi berdarah itu?

(49) Di mana mahasiswa diculik oleh orang tak dikenal itu sekarang?

(50) Aparat keamanan itu kenapa?

(51) Dia itu apa?

Dari contoh-contoh kalimat tanya bahasa Indonesia tersebut di atas, dapat dikatakan bahwa kata tanya pengisi fungsi sintaktis predikat dapat berwujud kata tanya apa, mengapa, bagaimana, siapa, berapa, di mana, dan kenapa. Demikian pula, peran semantisnya juga menyatakan makna yang beragam, yakni menyatakan makna perbuatan untuk data (45), makna keadaan untuk data (46), makna pelaku untuk data (47), makna jumlah untuk data (48) makna keberadaan untuk data (49), makna keadaan untuk data (50), dan juga makna identitas untuk data (51).

\subsubsection{Kata Tanya sebagai Pengisi Fungsi Objek}

Seperti halnya kata tanya pengisi fungsi predikat, kata tanya pengisi objek juga terdiri dari beberapa jenis, sebagai terlihat dalam kalimat-kalimat berikut.

(52) Para mahasiswa menuntuk apa?

(53) Masyarakat menyalahkan siapa?

(54) Para demonstran melemparkan apa ke aparat keamanan itu? 
Dari contoh di atas, tampak bahwa kata tanya pengisi fungsi objek cenderung ditempati oleh kata tanya apa dan siapa. Masing-masing kata tanya memiliki peran semantis yang beragam. Kata tanya apa pada data (52) memiliki makna sasaran, kata tanya siapa pada data (53) mamiliki makna penderita, dan kata tanya apa pada data (54) memiliki makna alat.

\subsubsection{Kata Tanya sebagai Pengisi Fungsi Keterangan}

Untuk mengetahui kata-kata tanya pengisi fungsi sintaktis keterangan ini dapat dilihat dalam kalimat-kalimat berikut.

(55) Korban dari arogansi aparat keamanan itu dirawat di mana?

(56) Kapan krisis moneter ini akan berakhir?

(57) Presiden SBY pergi ke Kuala Lumpur dengan siapa?

(58) Dengan apa aparat keamanan menembaki mahasiswa?

(59) Mengapa aparat keamanan menembaki mahasiswa?

(60) Makanan dan minuman itu disediakan untuk siapa?

Dari contoh-contoh di atas, terlihat bahwa kata-kata tanya pengisi fungsi sintaktis keterangan sangat beragam. Fungsi sintaktis tersebut dapat diisi oleh kata tanya di mana, kapan, siapa, dan mengapa. Masing-masing kata tanya yang menempati fungsi keterangan memiliki peran semantis yang berbeda-beda. Kata tanya di mana pada data (55) memiliki makna tempat, kapan pada data (56) memiliki makna waktu, dengan siapa pada data (57) memiliki makna peserta, degan apa pada data (58) bermakna alat, mengapa pada data (59) bermakna sebab, dan untuk siapa pada data (60) bermakna sasaran.

\section{SIMPULAN}

Berdasarkan keseluruhan pembahasan sebagai terurai di atas, beberapa simpulan yang dapat dikemukakan adalah sebagai berikut.

(1) Kalimat tanya dalam bahasa Indonesia adalah salah satu bentuk kalimat yang pada hakikatnya menanyakan suatu informasi atau untuk konfirmasi suatu hal;

(2) Kalimat tanya bahasa Indonesia dapat diuraikan dengan pemakaian pertikel tanya dan kata tanya;

(3) Ditinjau dari segi sintaktis, kata tanya dapat menduduki fungsi predikat, objek complement, dan keterangan; 
(4) Ditinjau dari segi semantis, kata tanya dapat memiliki makna tertentu seperti makna penderita, identitas, waktu, sebab, dan sebagainya.

(5) Berdasarkan jenisnya, kalimat tanya bahasa Indonesia dapat dibedakan menjadi dua, yakni, kalimat tanya konfirmatif, dan kalimat tanya informatif. Kalimat tanya konfirmatif biasanya ditandai dengan hadirnya partikel tanya seperti -kah, -kan, ya, apa, dan masa?, sedangkan kalimat tanya informatif ditandai dengan pemakaian kata tanya seperti siapa, apa, mengapa, kenapa, bagaimana, berapa, di mana, dan sebagainya.

\section{DAFTAR PUSTAKA}

Keraf, Gorys. 1984. Tata Bahasa Bahasa Indonesia. Ende, Flores: Nusa Indah.

Kridalaksana, Harimurti. 1994. Kelas Kata dalam Bahasa Indonesia. Jakarta: Gramedia Pustaka Utama.

Lapoliwa, Hans. 1990. Klausa Pemerlengkapan dalam Bahasa Indonesia. Yogyakarta: Kanisius. Moeliono, Anton M., dkk. 1993. Tata Bahasa Baku Indonesia. Jakarta: Depdikbud.

Ramlan, M. 1986. Ilmu Bahasa Indonesia: Sintaksis. Yogyakarta: CV. Karyono. 1987. Tata Bahasa Indonesia: Penggolongan Kata. Yogyakarta: Andi Offset.

Samsuri. 1981. Analisis Bahasa. Jakarta: Erlangga.

Sudaryanto. 1992. Metode Linguistik. Yogyakarta: Fakultas Sastra Universitas Gadjah Mada. Verhaar. 1984. Pengantar Linguistik. Yogyakarta: Gadjah Mada University Press. 